\title{
Hierarchical Task Analysis dalam pengembangan gagasan produk
}

\author{
W. Adhitia Guspara, ${ }^{1 *}$ W. Tridhatu Satwikasanti, ${ }^{1}$ Laode Jian ${ }^{1}$ \\ ${ }^{1}$ Program Studi Desain Produk, Fakultas Arsitektur dan Desain, Universitas Kristen Duta Wacana, Yogyakarta, Indonesia
}

\begin{abstract}
Human, have been claimed to be central in a world perspective and bring an another investigating in design science. One of the process development in the design process is using Hierarchy Task Analysis (HTA) for idea development through task analysis. This method constituted from interdisciplinary science between industrial design and ergonomic. In the process, HTA has been adjusted and developed for the design process requirement. This condition affects the process analysis and format of the HTA. The paradigm shift, give more access for a designer to addresses idea development. Furthermore, Human activities, how they do it, using what and what kind of problems that can happen is going focused on user interaction with the product. All of these analysis and idea development is conducted using scheme and sketches. The result of ideas sketches to be able to work on next step process, for example, work on paper models or clay models. The result of ideas sketches to be able to continue work on next step process, for example, product existing analysis and work on modells. Research and developing HTA method for product design had the use of action research approach. This process engages lecturer and student as a user of HTA method. Through this approach, be able to found appropriateness HTA method which solves provided a problem. The result of HTA development has a benefit for a student as a one of planning and product development to arise a product based on ergonomic.
\end{abstract}

Key words: product design, Hierarchy Task Analysis (HTA), ideation, design process, ideas sketches

\begin{abstract}
Abstrak
Manusia, telah diklaim sebagai pusat dalam perspektif dunia dan membawa pemikiran lanjut dalam keilmuan desain produk. Salah satu proses pengembangan dalam proses desain adalah menggunakan Hierarchy Task Analysis (HTA) untuk pengembangan gagasan produk melalui analisa perilaku. Metode ini didasari dari keilmuan interdisipliner antara desain produk dan ergonomi. Dalam perkembangannya, HTA mengalami penyesuaian terhadap tuntutan proses desain untuk mengembangkan gagasan produk. Kondisi ini berdampak terhadap proses analisa dan format dari HTA. Pergeseran tersebut, memberikan lebih banyak kemudahan bagi seorang desainer untuk membahas pengembangan gagasan. Aktivitas manusia, bagaimana mereka melakukannya, menggunakan apa dan apa jenis masalah yang dapat terjadi, menjadi fokus pada interaksi pengguna dengan produk. Analisa dan pengembangan ide tersebut dilakukan dengan menggunakan bagan kerja dan sketsa di tiap kegiatan. Hasil sketsa idea pada tahap ini dapat dilanjutkan pada proses selanjutnya, semisal analisa produk sejenis dan modelling. Penyelidikan dan pengembangan metode HTA untuk keperluan desain produk menggunakan pendekatan action research. Proses ini melibatkan dosen dan mahasiswa sebagai pengguna langsung metode HTA. Melalui pendekatan tersebut didapatkan pengembangan metode HTA yang tepat guna dan langsung menyentuh akar permasalahan. Hasil dari pengembangan metode HTA ini berguna untuk memudahkan mahasiswa dalam melakukan perancangan pengembangan produk berbasis ergonomi.
\end{abstract}

Kata kunci: desain produk, Hierarchy Task Analysis (HTA), pengembangan gagasan, proses desain, sketsa gagasan

\section{Pendahuluan}

Tulisan ini berlatar belakang penyelidikan tindak kelas dengan pendekatan action research (Somekh,
2008) dan merujuk pada pengembangan metode HTA (Stanton, 2006). Penyelidikan ini melibatkan kelas ergonomi (1 dan 2) dan kelas studio pengembangan produk berbasis ergonomi yang sudah dilakukan sejak

\footnotetext{
* Corresponding author e-mail : guspara@staff.ukdw.ac.id
} 
tahun 2013 hingga saat ini. Salah satu metode yang digunakan dalam kelas studio berbasis ergonomi tersebut adalah Hierarchy Task Analysis atau disingkat HTA (Arnett, 2003, 2005; Stanton, 2006; Stanton et al., 2013). Penggunaan metode tersebut ditujukan agar mahasiswa dapat melakukan pembahasan temuan dan mengembangkan gagasan produk berkaitan dengan kinerja atau kegiatan yang dilakukan oleh responden.

HTA merupakan sebuah metode yang didasarkan kepada konsep kinerja dan bagaimana mengatur prinsip kerja (Stanton, 2006). Pada banyak penyelidikan, metode HTA digunakan untuk meninjau efektifitas kerja dan kegiatan yang tidak tepat dilakukan sehingga dapat diperoleh produktivitas yang diinginkan. Perbaikan kinerja tersebut dilakukan melalui analisa perilaku dan merencanakan kinerja yang lebih efektif dengan atau tanpa melibatkan peralatan atau tools serta teknologi (Arnett, 2005; Sebillotte, 1988; Stanton, 2006; Stanton et al., 2013; Stanton \& Young, 1999).

Kedudukan HTA dalam pengembangan gagasan dan perancangan produk yang dilakukan pada kelas Ergonomi 1 dan 2 serta kelas studio ergonomi atau Desain Produk ke-4 di tahun 2013-2014 dimulai dengan melakukan proses seperti HTA pada umumnya. Proses melakukan metode ini diawali dengan serangkaian tahapan yang terdiri dari (Stanton et al., 2013): (1) menemukan dan menentukan jenis kegiatan yang akan dibahas; (2) mengumpulkan data berupa tahapan kerja, teknologi yang digunakan, interaksi antara manusia dengan mesin, interaksi antar anggota tim dan pengambilan keputusan; (3) merumuskan tujuan dari kegiatan yang akan dibahas; (4) merumuskan sub kegiatan yang dilakukan secara spesifik selama proses kerja; (5) merumuskan tindakan operasional yang dilakukan pada tiap sub kegiatan; (6) merencanakan tahapan kerja dengan mengacu kepada tujuan dilakukannya analisa.

Sebagai contoh adalah pengembangan produk bersifat inklusi dengan tema peralatan dapur atau sarana memasak yang menyertakan pengguna ekstrim difabel netra sebagai responden. Merujuk kepada tahapan yang dirumuskan oleh Stanton dkk (Stanton et al., 2013), maka urutan kegiatan yang diperoleh dari simulasi memasak yang dilakukan oleh difabel netra dapat dilihat pada Tabel 1.

Urutan kegiatan tersebut kemudian dituliskan dalam bentuk bagan (Gambar 1) yang membahas organisasi kerja penempatan dan pengambilan sayuran dan bahan mentah dalam kegiatan memasak.

Proses tersebut berjalan sesuai dengan dengan tujuan dari kegunaan metode HTA sampai kepada perencanaan kegiatan, namun kendala baru kemudian

muncul dalam tahap selanjutnya. Perkara yang muncul terletak pada tahap analisa perilaku dan pengembangan gagasan produk.

Mahasiswa mendapatkan kesulitan untuk menterjemahkan gagasan dari rencana kegiatan menjadi sketsa produk. Beranjak dari hal tersebut, maka metode HTA perlu dilanjutkan dengan mengembangkan sebuah prinsip dan format sebagai pembahasan temuan dan pengembangan gagasan (Stanton \& Young, 1999). Langkah yang kemudian dilakukan adalah memberikan pertanyaan pengarah (guiding question) berkaitan dengan HTA yang berfungsi sebagai kendali terhadap pengembangan prosedur (Stanton, 2006).

Melalui proses pengembangan tersebut, maka mahasiswa mendapatkan pemahaman mengenai variabel yang harus digunakan untuk membahas hasil temuan sekaligus mengembangkan gagasan sketsa produk. Sebagai contoh variabel yang harus diketahui adalah interaksi penguna dan produk saat tangan kiri menggenggam bahan yang akan dipotong dengan empat jari, kemudian menggeser dan mengatur jarak dengan area potong sehingga mendapatkan ukuran potongan yang sama. Melalui pemahaman variabel yang bekerja, maka mahasiswa akan mempunyai pertimbangan dalam pengembangan model alat potong atau iris, seperti bentuk, ukuran dan permukaan bidang telenan, cara serta pergerakan tangan kiri mengatur jarak antara bahan yang akan dipotong dengan pisau, cara tangan kanan memegang pisau memotong dan gerakan memotong atau mengiris, jenis pisau potong.

Tabel 1. Contoh urutan kegiatan utama dan sub kegiatan

\begin{tabular}{|c|c|c|}
\hline Tema & : & $\begin{array}{l}\text { pengorganisasian sayuran dan bahan mentah } \\
\text { dalam kegiatan memasak }\end{array}$ \\
\hline Kegiatan 1 & : & memilih bahan yang akan diolah. \\
\hline Kegiatan 2 & : & $\begin{array}{l}\text { membersihkan bahan; sub kegiatan (1.1) } \\
\text { mengambil baskom, (1.2) mengisi baskom } \\
\text { dengan air, (1.3) memasukkan bahan yang } \\
\text { akan dicuci, (1.4) mencuci bahan yang akan } \\
\text { diolah. }\end{array}$ \\
\hline Kegiatan 3 & : & $\begin{array}{l}\begin{array}{l}\text { memilah bahan } \\
\text { pengolahan. }\end{array} \\
\end{array}$ \\
\hline Kegiatan 4 & • & $\begin{array}{l}\text { mengupas bahan; sub kegiatan (4.1) } \\
\text { mengambil alas potong berupa telenan dan alat } \\
\text { potong berupa pisau, (4.2) mengupas atau } \\
\text { mengiris bahan, (4.3) membuang sampah sisa } \\
\text { kupasan atau irisan. }\end{array}$ \\
\hline Kegiatan 5 & ? & $\begin{array}{l}\text { menempatkan bahan ke tiap tempat } \\
\text { berdasarkan urutan pengolahan }\end{array}$ \\
\hline
\end{tabular}




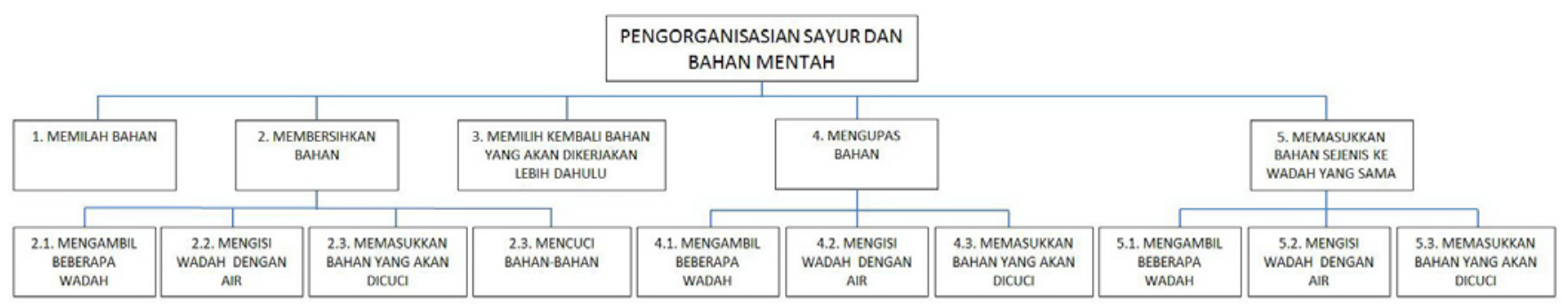

Gambar 1. Contoh bagan HTA

Penyelidikan tindak kelas, 2018

\section{Bahan dan Metode}

Penyelidikan tindak kelas ini bertujuan untuk mengembangkan proses pengajaran berkaitan dengan pemahaman mahasiswa terhadap proses pembahasan temuan serta pengembangan gagasan produk berbasis ergonomi. Proses tersebut melibatkan asisten pengajar dan mahasiswa studio Desain produk semester ke-4 $(\mathrm{n}=19$, usia $18 \pm 2.8$ tahun) sebagai rekan kerja penyelidikan supaya dapat lebih memahami variabel yang digunakan serta dapat memperkirakan arah pengembangan produk. Mahasiswa yang terlibat telah mempunyai pengetahuan anatomi dasar, anthropometri, biomekanika tubuh dan cara melakukan analisa perilaku. Berpijak pada model penyelidikan yang terdapat dalam action research, maka perubahan tata laksana HTA ini harus mampu mendorong mahasiswa dalam melakukan konstruksi pengetahuan (Somekh, 2008).

Langkah yang dilakukan dalam penyelidikan tindak kelas ini merujuk kepada prosedur kerja yang terdapat dalam action research (Somekh, 2008), seperti terlihat pada Gambar 2.

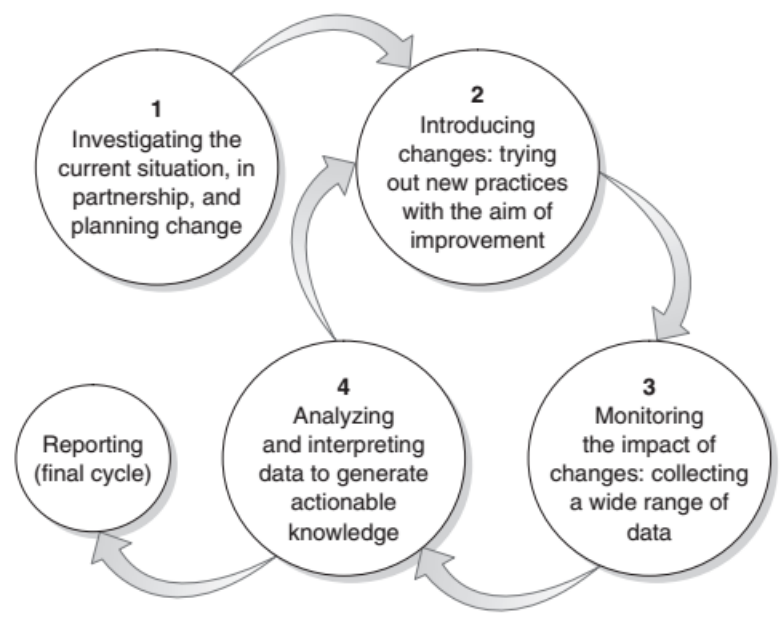

Gambar 2. Model of action research Bridget Somekh, 2008
Langkah 1: Mahasiswa yang telah memperoleh pembekalan penyusunan skema HTA, dibagi dalam grup kecil $(n=4)$ untuk mengamati perilaku subjek pengamatan dalam mengolah bahan makanan. Hasil pengamatan didokumentasikan ke dalam skema HTA secara individu berdasar pemilihan persoalan yang akan diselesaikan. Permasalahan dalam proses pengamatan, penyusunan HTA dan pengembangan gagasan produk yang dilakukan mahasiswa didokumentasikan oleh asisten dan dosen. Hasil temuan tersebut merupakan acuan pengembangan pertanyaan lanjutan.

Langkah 2: memberikan pertanyaan pengarah kepada mahasiswa. Pertanyaan pengarah ini berfungsi sebagai acuan mahasiswa dalam memahami variabel (i.e. konteks kegiatan, performa dan karakteristik pengguna, lingkungan, interaksi produk dengan pengguna) yang harus diketahui dalam melakukan pembahasan hasil temuan dan pengembangan gagasan produk. Pertanyaan pengarah diberikan sesuai dengan level yang tersedia pada metode HTA:

1. Level 0: Apakah sudah terdapat konteks yang jelas dan gambaran produk yang digunakan untuk melakukan kegiatan tersebut? Lalu bagaimana seharusnya?

2. Level 1: Dapatkah kita membagi kegiatan ini menjadi sub kategori? Bagaimana kita merumuskan sub kategori tersebut? Apa saja sub kategori yang seharusnya dituliskan supaya kegiatan tersebut dapat dilaksanakan? Apakah kita memerlukan gambaran produk pada tiap sub kategori kegiatan? Mengapa kita memerlukan gambaran produk tersebut?

3. Level 2: Bagaimana kita melakukan sub kategori kegiatan? Bagian tubuh mana sajakah yang kemudian berperan aktif dalam kegiatan? Bagaimana gerak bagian tubuh yang berperan? Apakah terdapat produk yang terlibat dalam kegiatan tersebut? Dapatkah kita 
menggambarkan interaksi bagian tubuh dengan produk yang digunakan?

4. Level 3: Apakah terdapat kesenjangan atau persoalan terhadap kegiatan tersebut? Apakah terdapat masalah dalam interaksi antara bagian tubuh dengan produk? Apa saja masalah yang muncul? Mengapa? Lalu seharusnya bagaimana?

Proses melalui pertanyaan pengarah yang diterima oleh mahasiswa dapat menghasilkan pengembangan metode HTA yang lebih mudah dipahami oleh mahasiswa. Hal tersebut dapat tercapai karena mahasiswa mendapatkan stimulus gagasan dalam melihat hubungan antara pengguna, produk dan lingkungan kerja.

Langkah 3: melakukan pengamatan dan dialog kepada proses yang dilakukan mahasiswa dalam mengembangkan metode HTA. Pengamatan dilakukan oleh dosen dan asisten dalam diskusi individual maupun per grup. Hal yang diamati mencakup perubahan format, sktesa produk, urutan kegiatan, dan interaksi produk dengan pengguna. Sedangkan dialog yang dilakukan adalah proses pemahaman mahasiswa terhadap langkah-langkah yang dilakukan dalam pengembangan metode HTA.

Langkah 4: melakukan reduksi temuan dengan menekankan kepada kebutuhan yang harus disertakan dan ditulis pada tiap level dalam metode HTA, yaitu berupa konteks kegiatan, produk yang terlibat, interaksi produk dengan pengguna. Selanjutnya adalah melakukan rumusan pengembangan metode berupa format bagan dan tata cara melakukan metode HTA yang sudah dikembangkan.

Langkah 5: membuat evaluasi mengenai proses pengembangan metode HTA dan melakukan desiminasi hasil penyelidikan tindak kelas.

\section{Hasil dan Pembahasan}

Hal pertama yang harus dipahami mahasiswa dalam melakukan penyusunan HTA adalah rangkaian kegiatan dapat dipilah berdasarkan kegiatan utama dan sub kegiatan. Penyusunan tersebut melibatkan beberapa pertimbangan dalam setiap levelnya (Tabel 2).

Contoh kasus yang digunakan dalam tulisan ini adalah pengembangan HTA pada kelas studio pengembangan produk berbasis ergonomi. Tema yang diusung pada contoh kasus ini adalah pengembangan produk berbasis desain inklusi dengan melibatkan responden tuna netra. Tujuan dari desain inklusi ini adalah memasukkan pengguna ekstrim sebagai prinsip pengembangan produk, sehingga produk yang dihasilkan akan mempunyai kemudahan tertentu bagi pengguna lain, semisal digunakan oleh orang tua untuk mengajarkan anaknya dalam kegiatan memasak atau orang lanjut usia yang sudah mulai mengalami penurunan kemampuan meraba dan melihat.

Tabel 2. Tata cara penyusunan HTA

\begin{tabular}{|c|c|}
\hline Level-0 & $\begin{array}{l}\text { Memutuskan tema atau topik yang akan } \\
\text { diselesaikan. } \\
\text { (eg. Pengorganisasian bahan mentah atau } \\
\text { sayuran). }\end{array}$ \\
\hline Level-1 & $\begin{array}{l}\text { Menentukan tujuan tugas dan kriteria kerja. } \\
\text { (eg. Kegiatan utama: mengupas bahan mentah } \\
\text { atau sayuran). }\end{array}$ \\
\hline Level-2 & $\begin{array}{l}\text { Melakukan identifikasi terhadap kegiatan } \\
\text { penyusun kerja. } \\
\text { (eg. Sub kegiatan: mengupas dan mengiris bahan } \\
\text { mentah atau sayuran). }\end{array}$ \\
\hline Level-3 & $\begin{array}{l}\text { Membuat perbaikan melalui rencana kerja. } \\
\text { (eg. Rencana kerja: (1.1) memilah dan memilih } \\
\text { bahan - (2.1) mengambil wadah dan mengisi } \\
\text { dengan air - (4.2) mengupas dan mengiris - (2.3) } \\
\text { memasukkan potongan kedalam wadah berisi air - } \\
\text { (2.4) mencuci potongan bahan atau sayuran dan } \\
\text { membuang air cucian) }\end{array}$ \\
\hline
\end{tabular}

Rumusan masalah berupa pertanyaan penelitian yang telah ditentukan oleh mahasiswa menjadi acuan refleksi. Pertanyaan penelitian dibangun dengan menggunakan penelusuran awal berupa literatur, role play dan pengamatan awal. Langkah ini ditujukan untuk meninjau kondisi serta variabel yang terlibat dalam rumusan masalah tersebut, dan kemudian dilanjutkan dengan penyelidikan terhadap responden dengan menggunakan simulasi praktik. Melalui penyelidikan yang dilakukan oleh mahasiswa melalui wawancara dan pengamatan, maka didapatkan urutan kegiatan, cara melakukan kegiatan dan produk atau alat yang terlibat. Setiap tahap kegiatan kemudian dituangkan dalam bentuk bagan seperti Gambar 1 .

Kerumitan pembahasan temuan dan perancangan yang ditemukan dalam studi ini terletak pada penerjemahan pemikiran verbal menjadi bahasa visual. Kerumitan tersebut berada pada wilayah cognitive learning dan tidak akan dibahas secara khusus pada penulisan ini. Penyelidikan dan penulisan ini ditujukan untuk mengembangkan metode HTA yang digunakan untuk pengembangan gagasan produk melalui sketsa. Pengembangan metode HTA versi visual ini tidak meninggalkan proses yang berlangsung pada umumnya. Perubahan yang terjadi dalam pengembangan metode HTA ini adalah dengan menambahkan bahasa visual pada tiap detil kegiatan. 
Tabel 3. Pengembangan tata cara penyusunan HTA

\begin{tabular}{|c|c|c|}
\hline Level-0 & : & $\begin{array}{l}\text { Memutuskan tema atau topik yang akan } \\
\text { diselesaikan dan menyertakan produk yang } \\
\text { digunakan. } \\
\text { (eg. Pengorganisasian bahan mentah atau sayuran } \\
\text { menggunakan baskom). }\end{array}$ \\
\hline Level-1 & : & $\begin{array}{l}\text { Menentukan kategori kerja dan menyertakan } \\
\text { produk yang terlibat. } \\
\text { (eg. Kegiatan utama: mengupas bahan mentah atau } \\
\text { sayuran menggunakan pisau dan mengiris atau } \\
\text { memotong menggunakan telenan). }\end{array}$ \\
\hline Level-2 & : & $\begin{array}{l}\text { Melakukan identifikasi terhadap interaksi produk- } \\
\text { pengguna-lingkungan kerja. } \\
\text { (eg. Sub kegiatan memotong: tangan kiri } \\
\text { memegang bahan mentah atau sayuran dengan } \\
\text { cara menggenggam menggunakan telapak tangan } \\
\text { dan lima jari, sedangkan tangan kanan memegang } \\
\text { pisau menggunakan lima jari serta telapak tangan } \\
\text { dan menjadikan jari telunjuk serta ibu jari sebagai } \\
\text { titik gaya). }\end{array}$ \\
\hline Level-3 & : & $\begin{array}{l}\text { Melakukan analisa produk melalui kesenjangan } \\
\text { yang terjadi. } \\
\text { (eg. Rencana kerja: pengembangan alat kupas } \\
\text { yang dapat menghasilkan ukuran potongan serupa } \\
\text { dengan kemudahan dalam pengaturan jarak antara } \\
\text { bahan mentah atau sayuran dengan pisau). }\end{array}$ \\
\hline
\end{tabular}

Melalui contoh yang diberikan (Tabel 3) untuk menjelaskan di tiap level, dapat dilihat bahwa bahasa verbal mempunyai kesulitan dalam menggambarkan detil kegiatan yang dilakukan. Langkah yang harus ditempuh kemudian adalah mengubah bahasa verbal tersebut menjadi bahasa visual sehingga lebih mudah untuk dipahami.

Hal penting dalam pengembangan metode HTA ini terletak pada tiga hal, yaitu klasifikasi hirarki tugas antar level, klarifikasi tentang cara dan alat yang terlibat dan analisa mengenai kinerja yang sudah dilakukan serta apa yang dimungkinkan terjadi (Stanton, 2006). Proses klasifikasi serta analisa tersebut dilakukan menggunakan pertanyaan pengarah dan hasil dari analisa dituangkan dalam bentuk visual, sehingga dimungkinkan terjadi cara berpikir visual tanpa meninggalkan peran penting dari metode HTA. Akurasi proses yang dilakukan dari penelusuran awal hingga penyelidikan sangat penting karena memberikan gambaran situasi yang harus digunakan untuk melakukan metode HTA. Melalui pertanyaanpertanyaan pada langkah ke-2, mahasiswa diajak untuk berpikir ulang tentang skema HTA yang telah mereka susun dan langsung menerjemahkan secara detil menggunakan bahasa visual atau sketsa (Gambar 3).

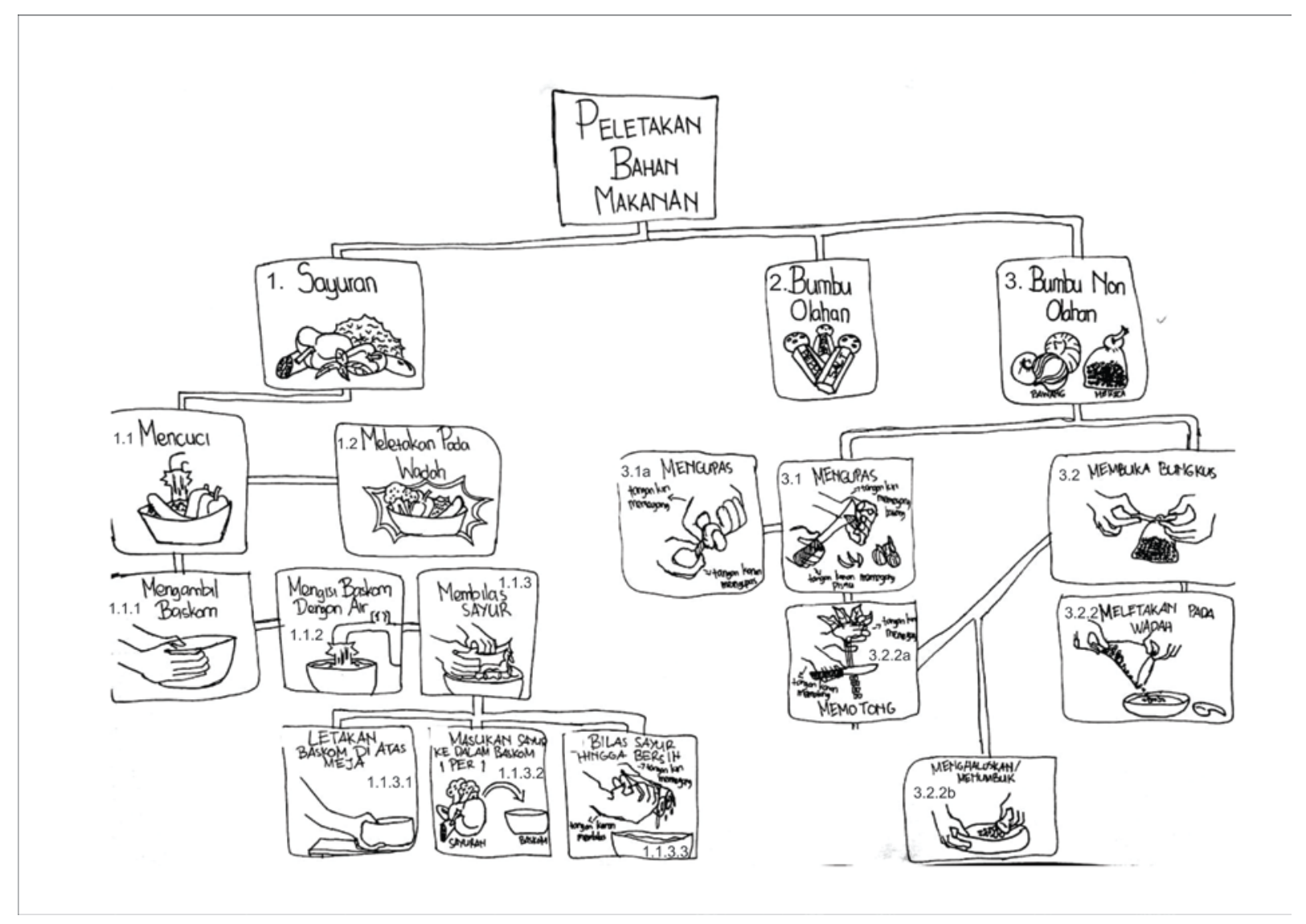

Gambar 3. Contoh HTA peletakan bahan makanan versi visual Penyelidikan tindak kelas, 2018 
Hal ini dilakukan dengan tujuan untuk memudahkan mahasiswa memahami kondisi yang terjadi, memicu pemikiran divergent, konvergensi dalam proses analisa kegiatan dan mengembangkan skenario yang dimungkinkan terjadi. Sketsa tersebut harus mampu menceritakan bagian tubuh yang bersentuhan langsung dengan produk serta bagaimana proses interaksi tersebut berlangsung (Gambar 3).

Setelah mendapatkan bagan urutan kegiatan kerja yang melibatkan sketsa, kemudian mahasiswa melakukan analisa dengan mengacu pada pertanyaan pengarah. Langkah ini bertujuan untuk membantu mahasiswa agar dapat mengetahui tahapan yang dianggap mengalami permasalahan desain melalui kebiasaan pengguna dalam menggunakan alat ataupun produk. Pengembangan bagan HTA visual akan menunjukkan posisi, arah gerakan dan bagian tangan yang digunakan untuk mengupas, membuka bungkus dan memotong sayuran (Gambar 3). yang kedua adalah menemukan serta menuliskan kemungkinan gagasan yang dapat dilakukan untuk mengatasi resiko atau kesalahan. Brainstorming dilakukan dalam bentuk kelompok dan tiap individu mengutarakan hal-hal atau situasi yang ditemukan ataupun memberikan kemungkinan gagasan yang dapat dilakukan melalui bahasa lisan atau menggunakan kartu (post-it) seperti pada Gambar 4.

Informasi yang terkumpul kemudian di dikerucutkan kembali melalui klasifikasi atau kategori informasi desain sejenis, misalnya informasi mengenai penyimpanan peralatan yang diperoleh dari kasus telenan, tempat bumbu, dan baskom, sehingga produk yang akan dikembangkan menggunakan konsep collapsible (Mollerup, 2001). Mahasiswa kemudian mengembangkan gagasan desain melalui rumusan pernyataan desain (design statement) yang berbunyi "sarana pengorganisasian pisau dan telenan yang memberi kemudahan akses serta penggunaan dengan menggunakan konsep collapsible”.

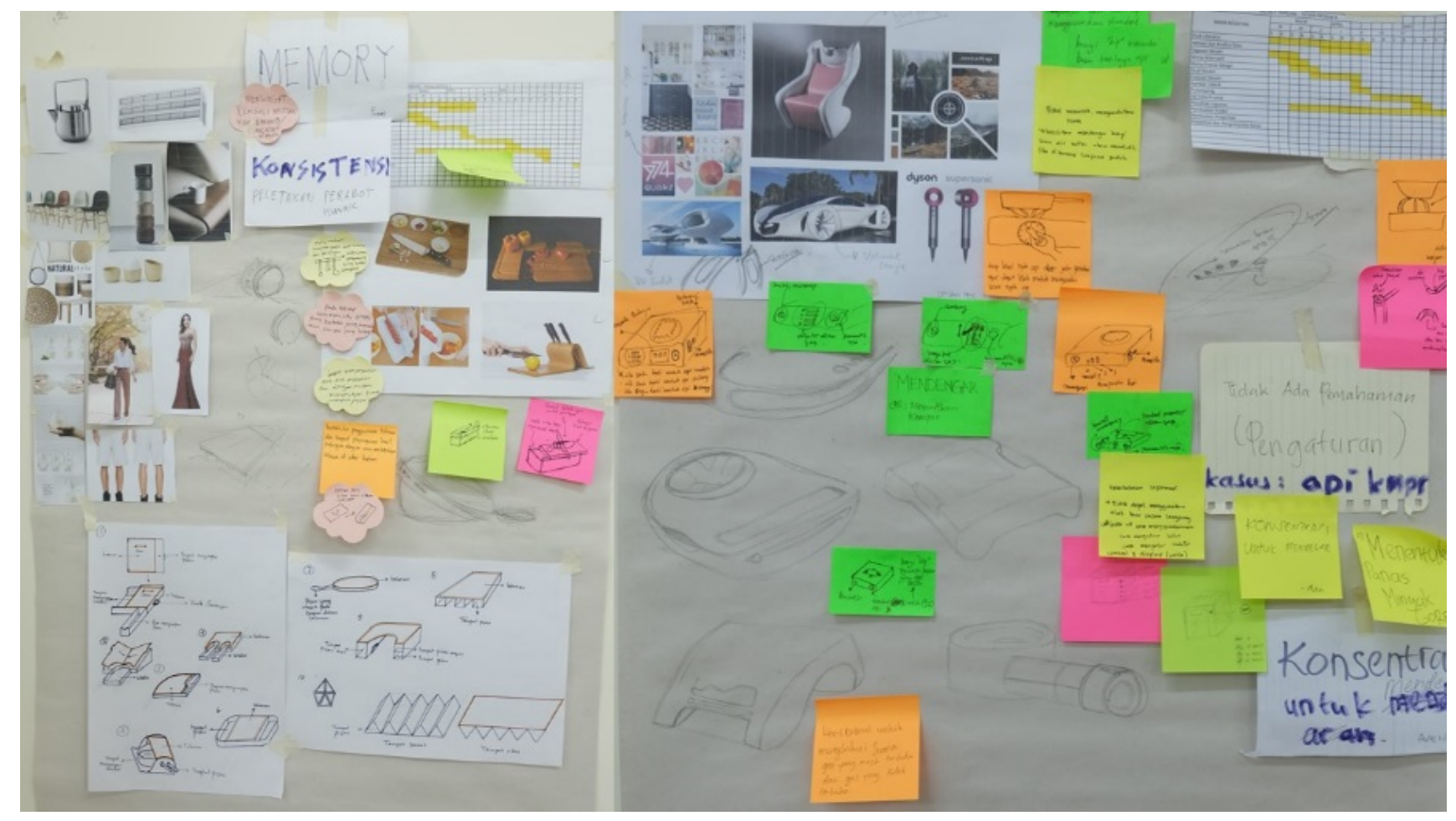

Gambar 4. Contoh proses Brainstorming Penyelidikan tindak kelas, 2018

Tahap selanjutnya adalah mengembangkan gagasan atau rencana pengembangan produk yang dihasilkan melalui HTA. Gagasan pengembangan produk dilakukan menggunakan metode brainstorming (Jones, 1970) melalui dua cara, pertama ialah menemukan serta menuliskan kemungkinan resiko atau kesalahan yang dapat terjadi, terutama pada interaksi pengguna, produk dan lingkungan kerja,
Melalui pernyataan desain tersebut, mahasiswa sudah mempunyai arah pengembangan desain dengan menampilkan fitur tambahan berupa kemudahan penyimpanan peralatan sehingga kehadiran produk dapat mempengaruhi perilaku pengguna (Lockton, Harrison, \& Stanton, 2010). Mengacu pada detil bagan HTA versi visual yang telah dikembangkan, beberapa perubahan dasar dalam pengembangan 
desain tersebut berupa: (1) dimensi yang sesuai dengan anatomi tangan; (2) mekanisme collapsible yang mempunyai kemungkinan untuk diterapkan adalah assembling, hinging, sliding, fanning dan concertina; (3) sistem kerja pengorganisasian besifat compact; (4) tekstur, pola dan warna yang tidak hanya menarik perhatian, tetapi juga memberi awareness bagi pengguna mengenai keselamatan; (5) bentuk bidang yang menegaskan area kerja tangan atau jari; (6) bentuk komponen beserta mekanisme yang memudahkan untuk membuka atau menutup.

Beranjak dari hal tersebut, kemudian mahasiswa membuat rencana terhadap urutan kegiatan tersebut dengan cara menambahkan atau mengurangi tahap kegiatan. Rencana kegiatan tersebut kemudian langsung dituangkan pada sketsa gagasan produk (Gambar 5).

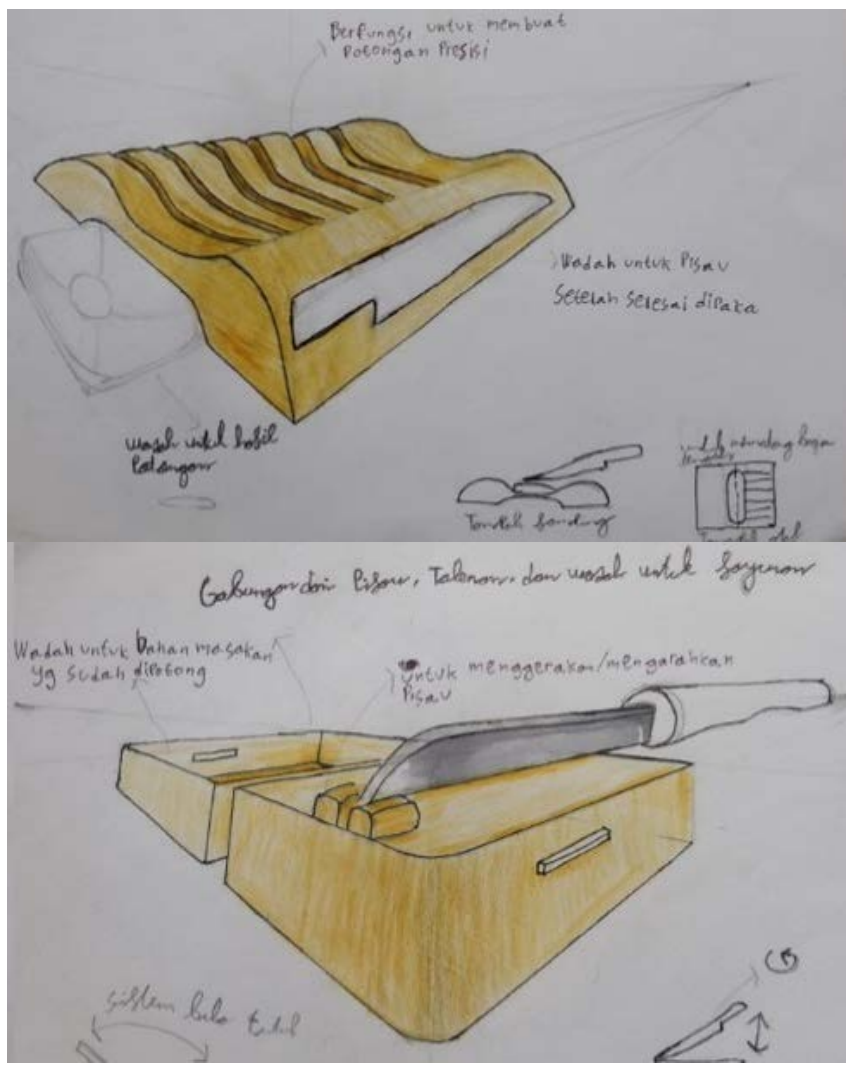

Gambar 5. Contoh sketsa pengembangan Desain Penyelidikan tindak kelas, 2018

Melalui proses yang dilakukan dalam pengembangan metode HTA visual, mahasiswa mempunyai kemudahan dalam melakukan pengembangan gagasan produk. Sketsa yang ditampilkan oleh mahasiswa seperti contoh Gambar 5, telah mampu memperlihatkan detil yang diperlukan dalam pengembangan produk, berupa interaksi pengguna dengan produk dan detil komponen produk.
Rincian dalam sketsa pengembangan gagasan produk juga telah mampu mendeskripsikan lebih dalam mengenai mekanisme serta cara pengoperasian produk.

\section{Kesimpulan}

Proses tindak kelas ini telah menghasilkan pengembangan metode HTA yang memudahkan mahasiswa dalam menganalisa perilaku dan pengembangan gagasan produk. Hasil dari penyelidikan tindak kelas berupa metode HTA visual ini kemudian akan dijadikan sebagai salah satu acuan untuk tahap analisa perilaku dan pengembangan gagasan produk berbasis ergonomi. Selain itu, metode HTA visual tersebut juga akan digunakan sebagai materi ajar pada kelas Ergonomi 1 dan 2 serta kelas Studio Desain Produk 4 (Human Center Design).

Pengembangan HTA visual masih perlu dilanjutkan lagi terutama pada tahap pemilihan material, bentuk dan fungsi komponen, hubungan bentuk antara tekstur, warna, ornamen, bidang terhadap perilaku serta kebutuhan pengguna. Berdasarkan kondisi tersebut, maka kemungkinan pengembangan metode yang merupakan kerja interdisipliner antara keilmuan ergonomi dan desain produk masih terbuka luas, sebagai contoh adalah interaksi pengguna dan produk berdasar kepada cognitive learning, pengembangan persona (persona life cycle) dan emotional design.

\section{Daftar pustaka}

Arnett, J. (2003). Hierarchical Task Analysis. In E. Hollnagel (Ed.), Handbook of Cognitive Task Design (pp. 17-35). New Jersey: Erlbaum Mahwah. https://doi.org/10.1017/CBO9781107415324.004

Arnett, J. (2005). Hierarchical Task Analysis (HTA). In N. Stanton, A. Hedge, K. Brookhuis, E. Salas, \& K. Hendrick (Eds.), Handbook of Human Factors and Ergonomics Methods (pp. 33-1-33-7). Florida: CRC Press.

Jones, J. C. (1970). Design Methods. Hertfordshire: John Willey \& Sons Ltd.

Lockton, D., Harrison, D., \& Stanton, N. (2010). The Design with Intent Method: A design tool for influencing user behaviour. Applied Ergonomics, 41, 382-392. https://doi.org/10.1016/j.apergo.2009.09.001

Mollerup, P. (2001). Collapsible. San Fransisco: Chronicle Books LLC.

Sebillotte, S. (1988). Hierarchical Planning as Method for Task Analysis: the Example of Office Task Analysis. Behaviour and Information Technology. Behaviour and Information Technology, 7(3), 275-293.

Somekh, B. (2008). Action Research. In L. M. Given. (Ed.), The Sage Encyclopedia of Qualitative Research Methods (pp. 4-6). California: SAGE Publications, Inc. 
Stanton, N. (2006). Hierarchical task analysis: Developments, applications, and extensions. Applied Ergonomics, 37, 55-79. https://doi.org/10.1016/j.apergo.2005.06.003

Stanton, N., Salmon, P. M., Rafferty, L. A., Walker, G. H., Baber, C., \& Jenkins, D. P. (2013). Human Factor Methods: A Practical Guide for Engineering and Design. Farnham: Ashgate Publishing Limited.

Stanton, N., \& Young, M. S. (1999). A Guide to Methodology in Ergonomics. New York: Taylor \& Francis Inc. 